Uniwersytet im. Adama Mickiewicza, Poznań

\title{
Pozycja i kompetencje rady programowej w spółce publicznej radiofonii i telewizji
}

Wa wstępie warto przypomnieć, że zgodnie z ustawą z dnia 29 grudnia wizji działają wyłącznie w formie jednoosobowej spółki akcyjnej Skarbu Państwa. Choć taka forma organizacyjna, budzi wątpliwości i zastrzeżenia, to przeważa argumentacja, że z uwagi na dorobek doktryny i judykatury, spółka akcyjna zapewnia największą pewność prawną. Trudno zgodzić się z takimi twierdzeniami, jeżeli zważy się na dotychczasowe doświadczenia związane z funkcjonowaniem spółek radiofonii i telewizji publicznej. Poza tym należy pamiętać, iż taka forma może kłócić się z ideą misji publicznej tych podmiotów ${ }^{2}$.

Obecnie system mediów publicznych tworzą „Telewizja Polska - Spótka Akcyjna”, której celem wskazanym w ustawie jest tworzenie i rozpowszechnianie ogólnokrajowych programów I, II i TV Polonia oraz regionalnych programów telewizyjnych. Takie ośrodki mają swoje siedziby w: Białymstoku, Bydgoszczy, Gorzowie Wielkopolskim, Gdańsku, Katowicach, Kielcach, Krakowie, Lublinie, Łodzi, Opolu, Olsztynie, Poznaniu, Rzeszowie, Szczecinie, Warszawie, Wrocławiu. Natomiast struktura organizacji radiofonii publicznej jest znacznie bardziej rozbudowana. Bowiem obecnie funkcjonują:

- spółka „Polskie Radio - Spółka Akcyjna”, zawiązana w celu tworzenia i rozpowszechniania ogólnokrajowych programów radiowych i programów dla odbiorców za granicą;

- spółki zawiązane w celu tworzenia i rozpowszechniania regionalnych programów radiowych.

Aktualnie funkcjonuje siedemnaście takich podmiotów, a mianowicie Radio Wrocław, radio Pik z siedzibą w Bydgoszczy, Radio Lublin, Radio

1 T.j. Dz. U. 2004, Nr 253, poz. 2531. Dalej zwana ustawą.

2 Zob. szerzej J. Sobczak, J. Skrzypczak, Czy TVP potrzebne jest prawo handlowe?, „Palestra” 2006, nr 1-2, s. 79-93. 
Zachód w Zielonej Górze, Radio Łódź, Radio Kraków, Radio dla Ciebie w Warszawie, Radio Opole, Radio Rzeszów, Radio Białystok, Radio Gdańsk, Radio Koszalin, Radio Katowice, Radio Kielce, Radio Olsztyn, Radio Merkury w Poznaniu, Radio Szczecin ${ }^{3}$.

Nadana przez ustawodawcę forma organizacyjna spółki akcyjnej każe stosować tu przepisy kodeksu spółek handlowych ${ }^{4}$. Jedynie zgodnie $\mathrm{z}$ art. 26 ust. 4 stanowi, iż do spółek tych nie stosuje się art. 312 i 402 k.h. ${ }^{5} \mathrm{Na}$ marginesie warto zauważyć, że oczywiście w dzisiejszym stanie prawnym chodzi o ustawę z dnia 15 września 2000 r. Kodeks spółek handlowych ${ }^{6}$.

Zważywszy na powyższe w aktualnym stanie prawnym władzami spółki są: zarząd, rada nadzorcza oraz walne zgromadzenie. Zgodnie z art. 27 ust. 1 ustawy organem wykonawczym spółki jest zarząd, liczący od jednego do pięciu członków, którego kadencja trwa cztery lata. Członków zarządu, w tym prezesa zarządu, powołuje i odwołuje rada nadzorcza większością dwóch trzecich głosów w obecności co najmniej trzech czwartych jej członków. Do kompetencji zarządu spółki pod przewodnictwem prezesa należy zarządzanie tym podmiotem i reprezentowanie go na zewnątrz. Ponadto wszelkie sprawy związane z prowadzeniem spółki, nie zastrzeżone przez ustawę z dnia 29 grudnia 1992 roku o radiofonii i telewizji oraz ustawę z 15 września 2000 r. - Kodeks spółek handlowych, ewentualnie przez statut spółki, do kompetencji innych organów należą do zakresu działania zarządu. W statutach spółek z reguły przesądza się, że zarząd spółki zatrudnia pracowników spółki, określa ich zakres obowiązków i zasady wynagrodzenia.

Drugim organem spółki jest rada nadzorcza, która liczy od pięciu do dziewięciu członków, powoływanych przez Krajową Radę Radiofonii i Telewizji, z wyjątkiem jednego, którego powołuje minister właściwy do spraw Skarbu Państwa. Pracami tego organu kieruje przewodniczący, wybierany przez samą radę spośród członków tego organu. Kadencja trwa

3 Patrz szerzej R. Kowalczyk, Radio lokalne w Polsce, Poznań 2007, s. 45-68.

${ }^{4}$ Zob. szerzej na ten temat J. Sobczak, J. Skrzypczak, Czy TVP potrzebne jest prawo handlowe?, „Palestra” 2006, nr 1-2, s. 79-93.

${ }^{5}$ Art. 313 k.h. dotyczył badania sprawozdań założycieli przez biegłych rewidentów, a art. 396 k.h. obowiązku zwoływania walnego zgromadzenia w drodze ogłoszeń. Zob. szerzej, J. Sobczak, Radiofonia i telewizja. Komentarz do ustawy, Kraków 2001, s. 355; T. Sojka, Kodeks handlowy - Komentarz, Zielona Góra 1993, s. 224-225, 276-277. Zob. też J. Sobczak, J. Skrzypczak, op. cit., s. 79.

${ }^{6}$ Dz. U. Nr 94, poz. 1037 z późn. zm. Tak też J. Sobczak, J. Skrzypczak, op. cit., s. 79 . 
trzy lata. Zgodnie z art. 28 ust. 6 konieczne jest uzyskanie zgody rady nadzorczej w następujących czynnościach:

1) nawiązywanie i rozwiązywanie stosunku pracy z osobami zajmującymi stanowiska kierownicze określone w statucie spółki;

2) zawarcie lub przystapienie przez spółkę do umowy zbiorowej z przedstawicielami pracowników;

3) zawiązanie bądź przystąpienie do spółki innej niż spółka, o której mowa w art. 26 ust. 1, a także nabycie lub zbycie udziałów albo akcji w takiej spółce

4) zbycie lub obciążenie nieruchomości.

Zgodnie z art. 29. 1. ustawy w walnym zgromadzeniu Skarb Państwa reprezentowany jest przez ministra właściwego do spraw Skarbu Państwa. Zarząd spółki nie jest związany poleceniami i zakazami ustanowionymi przez walne zgromadzenie, jeżeli dotyczą one treści programu. Zmiana statutu spółki wymaga uprzedniej zgody Krajowej Rady.

Przypomnieć na wstępie należy, iż w obecnym stanie prawnym tj. zgodnie $\mathrm{z}$ art. 28a ust. 1 ustawy o radiofonii i telewizji rady programowe publicznej radiofonii i telewizji liczą 15 członków, których powołuje Krajowa Rada Radiofonii i Telewizji, a ich kadencja trwa 4 lata $^{8}$. Przy czym 10 członków rady programowej reprezentuje ugrupowania parlamentarne. I tu pojawić mogą się wątpliwości według jakiego klucza czy parytetu należy kierować się w procesie wyłaniana składów takich rad w tej grupie. Czy każde ugrupowanie winno mieć swojego przedstawiciela? W przypadku Senatu oznaczałoby to, że właściwie każdy senator mógłby domagać się swojego reprezentanta. Chyba jednak należy twierdzić, że skład rad programowych powinien odzwierciedlać aktualnie panujący układ sił politycznych i pozycję poszczególnych ugrupowań w Sejmie RP i Senacie RP. Tyle, że to może rodzić kolejne problemy. Otóż można zastanawiać się czy istnieje konieczność zmiany składu po rozpisaniu nowych wyborów9

7 J. Sobczak, J. Skrzypczak, op. cit., s. 80-81.

8 W kwestii prac legislacyjnych dotyczących rad programowych zob. R. Chruściak, Krajowa Rada Radiofonii i Telewizji w systemie politycznym i konstytucyjnym, Warszawa 2007, s. 240-241. Autor relacjonując kolejne projekty opisuje rozwiązanie, iż radę programową mieli tworzyć przedstawicie m.in. klubów poselskich, organizacji społecznych oraz kościołów i związków wyznaniowych. W późniejszych projektach np. rządu T. Mazowieckiego projektu ustawy o instytucjach publicznej radiofonii i telewizji, KRRT utraciła prawo powoływania rad programowych. Kwestię tę odsyłano do rozstrzygnięcia statutom spółek.

9 J. Sobczak, op. cit., s. 382. 
Takie rozwiązanie pozostawałoby jednak w konflikcie z zasadą kadencyjności tego podmiotu. Zgodnie z przytoczonym przepisem pozostałych 5 powołuje się z grona osób legitymujących się dorobkiem i doświadczeniem w sferze kultury i mediów. Tak wskazane kryteria także są nieostre i mogą rodzić szereg wątpliwości.

Dodajmy nadto, że w pierwotnym brzmieniu ustawy obowiązywał art. 28 ust. 7 zgodnie z którym ,statut spółki określa zasady powoływania i funkcjonowania rady programowej jako organu opiniodawczo-doradczego zarządu w sprawach programowych. Rada programowa reprezentuje ugrupowania parlamentarne oraz społeczne interesy i oczekiwania związane z działalnością programową spółki”. Jak z powyższego wynika do wejścia w życie nowelizacji z 1995 r. kwestie związane z procedura powoływania, jak i szczegółowymi kompetencjami takich ciał pozostawiono do rozstrzygnięcia statutowi. Ustawa w każdym razie nie przesądzała, iż należy to do Krajowej Rady. Również w sposób mało precyzyjny rozstrzygnięto wówczas kompetencje rad, stanowiąc jedynie, iż jest to organ opiniodawczo-doradczy zarządu, ale jedynie w sprawach programowych. Taki stan prawny obowiązywał do wejścia w życie ustawy z dnia 29 czerwca 1995 r. o zmianie ustawy o radiofonii i telewizji oraz o zmianie niektórych innych ustaw ${ }^{10}$. Dodać tu należy, że prezydent RP wniósł do Trybunału Konstytucyjnego o stwierdzenie niezgodności niektórych przepisów tego aktu normatywnego z Konstytucją ${ }^{11}$, zarzucając, iż ,nie określono [...] w sposób czytelny charakteru, ustroju i pozycji tych rad w stosunku do organów spółek. Wykreowano więc organ, którego ustroju i charakteru nie da się ustalić. Ponadto w art. 28a w ust. 2 stwierdzono, że członkowie rad reprezentują społeczne interesy i oczekiwania związane z działalnością programową, co nasuwa konkluzję, że rady stały się stróżami interesu społecznego w publicznej radiofonii i telewizji, a to zaś pozostaje w sprzeczności z przepisami konstytucyjnymi, które rolę stróża wyznaczyły Krajowej Radzie" ${ }^{\text {"12 }}$. Orzeczeniem z dnia 28 listopada 1995 r. ${ }^{13}$ Trybunał Konstytucyjny uznał jednak, że zaskarżone przepisy są zgodne z ustawą zasadniczą.

10 Dz. U. Nr 142, poz. 701.

11 R. Chruściak, op. cit., s. 241.

12 Ibidem, s. 241.

13 Orzeczenie Trybunału Konstytucyjnego z dnia 29 listopada 1995 r., sygn. akt K 17/95, opublik. w LexPolonica nr 320480, OTK 1995/II, poz. 37. 
Jak podkreślił TK w uzasadnieniu tego orzeczenia „Rada programowa nie jest organem spółki. Analiza art. 1 pkt 11 oraz analiza art. 26-30 obowiązującej ustawy o radiofonii i telewizji odnoszących się wprost do spółek w radiofonii i telewizji a także analiza kodeksu handlowego prowadzi do wniosku, że w strukturze władz spółek w publicznej radiofonii i telewizji nie nastąpiły żadne zmiany. W szczególności nie postanowiono, aby rada programowa weszła w skład struktury organizacyjnej władz spółki jako statutowy organ. Znowelizowane postanowienia ustawy dotyczące rad programowych nie naruszają układu organów spółki i ich kompetencji. Rada programowa nie jest ani organem zarządzającym ani nadzorczym spółki. [...] Rada programowa, co przede wszystkim wynika $\mathrm{z}$ analizy art. $1 \mathrm{pkt} 11$, jest organem pomocniczym, opiniodawczo-doradczym rady nadzorczej. Co prawda ustawodawca zrezygnował w ustawie nowelizującej z określenia rady jako organu opiniodawczo-doradczego (choć pozostawił to określenie w art. 30 ust. 4 nazywając radę programową oddziału organem opiniodawczo-doradczym dyrektora terenowego oddziału spółki), ale nie można na tej podstawie twierdzić, że w ten sposób rady straciły cechę organu pomocniczego, opiniodawczo-doradczego organu spółki. Rozstrzygający dla oceny rady jako organu pomocniczego jest charakter podejmowanych przez nią uchwał. Otóż: «Rada programowa podejmuje uchwały zawierające oceny poziomu i jakości programu bieżącego oraz programów ramowych. Uchwały w sprawach programowych podejmowane większością głosów w obecności co najmniej połowy składu rady są przedmiotem obrad i postanowień rady nadzorczej», wyraźnie wskazuje, że uchwały rady nie mogą wywoływać żadnych skutków prawnych wobec podmiotów innych niż rada nadzorcza i że jeżeli miałyby mieć charakter wiążący (np. zarząd spółki), to musiałyby przybrać postać uchwały rady nadzorczej. Uchwały rady programowej, według tej konstrukcji, która jest zapisana $\mathrm{w}$ proponowanym art. 28a ust. 3, z prawnego punktu widzenia są jedynie opiniami dla rad nadzorczych. Rada nadzorcza mająca obowiązek rozpatrzyć te opinie może je przyjąć bądź odrzucić. Gdyby uchwały rady programowej miały mieć charakter wiążący - choć trudno sobie taką sytuację wyobrazić, aby podmiot nie będący organem spółki miał podejmować decyzje wiążące - to ustawa musiałaby wyraźnie tak postanowić"14.

14 Ibidem. 
Podzielając powyższy pogląd należy podkreślić, że w obecnym brzmieniu art. 28a ust. 2 ustawy członkowie tego ciała reprezentują społeczne interesy i oczekiwania związane z działalnością programową spółki. Zarząd spółki zgodnie z postanowieniami ustawy powinien zapewnić członkom rady programowej organizacyjne i finansowe warunki dokonywania ocen poziomu i jakości wyemitowanego programu, badania jego odbioru oraz zlecania niezależnych badań dotyczących percepcji programu i jego społecznych skutków. Na marginesie warto odnotować, iż członkom rady programowej przysługuje dieta wypłacana przez spółkę w wysokości ustalonej przez Krajową Radę ${ }^{15}$.

Kompetencje rady programowej unormowano w aktualnie obowiązującym ust. 3 art. 28 a ustawy ${ }^{16}$. Zgodnie $\mathrm{z}$ tym przepisem rada programowa podejmuje uchwały w sprawach programowych (większością głosów w obecności co najmniej połowy składu rady), zawierające oceny poziomu i jakości programu bieżącego oraz programów ramowych. Cytowany powyżej przepis stanowi dalej, iż uchwały takie są przedmiotem obrad i postanowień rady nadzorczej. Jak słusznie zauważa się w doktrynie, rada programowa jest wyłącznie organem opiniodawczo-doradczym organów spółki i to tylko w sprawach programowych ${ }^{17}$. Przytoczony przepis tylko w niewielkim stopniu określa zasady i formy funkcjonowania takich ciał $^{18}$. Zatem kwestie te powinien regulować w sposób szczegółowy statut spółki ${ }^{19}$. Także zdaniem K. A. Wąsowskiego ,rady programowe stanowią swoiste ciała opiniodawczo-doradcze rad nadzorczych spółek publicznej radiofonii i telewizji” ${ }^{20}$. Podzielić należy także pogląd, iż „kompetencje rady programowej ograniczone są wyłącznie do spraw programowych,

15 Przykładowo dieta dla przewodniczącego rady programowej od 1 stycznia $2003 \mathrm{r}$. wynosiła 353 zł, a dla członków rady 235 zł. W sumie w okresie od 1996-2003 koszty diet rady programowej TVP S.A. wynosiły 1226,1 tys. zł, a w spółkach radiofonii publicznej 2243 tys. zł, łącznie 3 469,1 tys. złotych. Źródło: Informacja o podstawowych problemach radiofonii $i$ telewizji za rok 2003, KRRTV, Warszawa, marzec 2004, s. 31 .

16 Art. 28a został dodany w art. 1 pkt 11 ustawy z dnia 29 czerwca 1995 r. o zmianie ustawy o radiofonii i telewizji oraz o zmianie niektórych innych ustaw (Dz. U. $\mathrm{Nr}$ 142, poz. 701). Jednocześnie na mocy tej nowelizacji skreślono dotychczasowy ust. 7 art. 28 ustawy.

17 J. Sobczak, Radiofonia i telewizja. Komentarz do ustawy, Kraków 2001, s. 380-381.

18 R. Chruściak, op. cit., s. 241.

19 J. Sobczak, op. cit., s. 381.

20 Tak K. A. Wąsowski, Status prawny Krajowej Rady Radiofonii i Telewizji-próba charakterystyki, „Kwartalnik Prawa Publicznego” 2004, nr 1, s. 223. 
a więc doboru poszczególnych audycji, proporcji między nimi, ogólnych założeń działalności radia czy telewizji. Tym samym rada ta nie ma podstaw do wypowiadania się w sprawach kadrowych, technicznych, gospodarczych, prawnych itd. ${ }^{21}$

Zgodzić należy się także z poglądem, iż rada programowa nie jest organem spółki. Taki wniosek wynika zarówno z analizy postanowień Kodeksu spółek handlowych, jak i ustawy o radiofonii i telewizji ${ }^{22}$. Należy podzielić także stanowisko, iż „ustawa, pozostawiając statutowi spółki uregulowania nie tylko zasad powoływania, ale i form funkcjonowania rady programowej, nie wypowiada się co do tego, czy korzystanie z jej opinii będzie obowiązkiem czy tylko prawem zarządu. Nie ma jednak w świetle obowiązujących przepisów przeszkód, aby rada wypowiadała się w kwestiach programowych z własnej inicjatywy. Postępowanie przez zarząd wbrew wskazaniom rady programowej nie może wobec opiniodawczego charakteru tego organu, rodzić dla zarządu spółki bezpośrednio żadnych negatywnych skutków. Fakt ten może stać się jednak podstawą oceny funkcjonowania zarządu przez walne zgromadzenie lub radę nadzorczą",23.

Warto zwrócić uwagę na jeszcze jedną kwestię, a mianowicie na kompetencje ustawowych (a tym samym statutowych) organów spółek radia publicznego. Przypomnieć zatem należy, iż zgodnie w art. 26 ust. 4 ustawy o radiofonii i telewizji do spółek publicznej radiofonii i telewizji stosuje się, z zastrzeżeniem art. 27-30 ustawy, przepisy Kodeksu spółek handlowych z wyjątkiem art. 312 i 402 . Skoro tak to należy przytoczyć w pierwszej kolejności art. 368. § 1 k.s.h., zgodnie z którym zarząd prowadzi sprawy spółki i reprezentuje spółkę. Przyjmuje się, że do kompetencji zarządu należą wszystkie sprawy, które nie zostały zastrzeżone do kompetencji innych organów spółki. Jak słusznie zauważa się w doktrynie ograniczenie lub wyłączenie kompetencji zarządu może wynikać tylko $\mathrm{z}$ ustawy ${ }^{24}$. Z kolei zgodnie $\mathrm{z}$ art. $382 \S 1$. k.s.h. rada nadzorcza sprawuje stały nadzór nad spółką we wszystkich dziedzinach jej działalności ${ }^{25}$.

$\mathrm{Z}$ punktu widzenia rozpatrywanego tu problemu, istotne znaczenie ma właściwa wykładnia postanowienia ust. 5 art. 28a ustawy o radiofonii i te-

21 J. Sobczak, op. cit., s. 381.

22 Ibidem, s. 381.

23 Ibidem.

24 J. Frąckowiak, Kodeks spółek handlowych, Komentarz, Warszawa 2001, passim.

25 Szerzej J. Sobczak, J. Skrzypczak, op. cit., s. 79 i n. 
lewizji. Przypomnieć tu należy, że zgodnie z tym przepisem „Zarząd spółki zapewnia członkom rady programowej organizacyjne i finansowe warunki dokonywania ocen poziomu i jakości wyemitowanego programu, badania jego odbioru oraz zlecania niezależnych badań dotyczących percepcji programu i jego społecznych skutków”. Opierając się na wykładni językowej, konstrukcja tego przepisu mogłaby sugerować, że na podstawie takiej regulacji rodzą się jakieś szczególne roszczenia rady programowej wobec zarządu, a właściwie nawet każdego z członków takiego ciała. Należy jednak - jak się wydaje - kierując się wskazaniami wykładni funkcjonalnej, a w szczególności uwzględniając rolę i pozycję rady programowej, wykładać postanowienia tego przepisu w kontekście nakreślonych kompetencji i charakteru tego ciała. Zatem ust. 5 art. 28a sprowadzić należy właściwie do „kwestii organizacyjnej”, a mianowicie, iż to zarząd spółki publicznego radia lub telewizji sprawuje organizacyjną i finansową „opiekę” nad działalnością rady programowej, zapewniając źródła finansowania. Do takiego wniosku skłania także okoliczność, iż w istocie - zgodnie z treścią przytoczonych powyżej przepisów - to zarząd jest odpowiedzialny za finansową kondycję spółki. Zatem uchwały rady programowej zawierające jakieś wytyczne czy nawet polecenia $i$ to nawet dotyczące sfery programowej (np. przeprowadzenie badań opinii publicznej), wtedy gdyby to wiązałoby się ze sporym wydatkiem, niekiedy niemożliwym do spełnienia (lub niebezpiecznym dla kondycji finansowej spółki), nie będą w żadnym stopniu wiążące dla organów spółki. Tym bardziej, że przecież takimi wynikami organy spółki mogą dysponować i moga je udostępnić temu ciału. Powtórzyć raz jeszcze wypada, że rada programowa spółki jest wyłącznie organem opiniodawczo-doradczym rady nadzorczej. A skoro tak to należy przyjąć, że działa w celu lepszego wykonywania swych funkcji przez organy spółki, które przecież ponoszą pełną odpowiedzialność za działalność spółki, w tym za wyniki finansowe.

Poza tym, gdyby przyjąć jednak odmienny wniosek i twierdzić, że zarząd byłby zobligowany do wykonania takiej uchwały, to przecież ewentualne kolejne uchwały (pozytywnie lub negatywnie oceniające działalność programową spółki), które zostałaby podjęte na podstawie takich badań, miałyby już wyłącznie charakter opiniodawczy.

Przypomnieć raz jeszcze należy, iż organem kontrolnym w spółce jest wyłącznie rada nadzorcza. Oczywiście nie można wykluczyć, że rada programowa może podjąć stosowną uchwałę i występować $\mathrm{z}$ odpowiednim wnioskiem czy sugestią do rady nadzorczej. Ta jednak jest w pełni suwerenna w podejmowaniu decyzji. Zważywszy na powyższe należy stwier- 
dzić, iż w obecnym kształcie przytoczonych przepisów rada programowa nie może skutecznie zobowiązać zarządu do dokonania określonych czynności prawnych czy faktycznych. Oczywiście rada może w świetle art. 28a ust. 5 zwracać się do zarządu podkreślając konieczność dokonania określonych działań. W przypadku odmowy może także wystąić ze stosownymi wnioskami do rady nadzorczej. Podobnie należy oceniać sytuacje, gdyby rada programowa próbowała sobie uzurpować uprawnienia do kontroli konkretnych czynności prawnych podejmowanych w imieniu spółki przez kompetentny jej organ. I tak przykładowo rada nie ma zatem wglądu w etapy postępowania przetargowego, który jest sposobem dokonania czynności prawnej. Tym bardziej nie ma prawa do „akceptowania” wyników takiej procedury przetargowej. Przy czym pojęcie ,akceptowanie" rozumiane jest tu jako wywierające skutki prawne skwitowanie działań zarządu. Bo oczywiście rada może wyrazić swoją opinię w tym zakresie, pod warunkiem, że dotyczyć to będzie sfery programowej nadawcy. I takie stanowisko może być dla podjętej przez zarząd decyzji i działań akceptujące lub nie. Nie wywiera to jednak bezpośrednio żadnego skutku dla zarządu. Jak już wyżej sygnalizowano rola i zadania Rady Programowej wynikają z jej charakteru, tj. ciała opiniodawczo-doradczego. Nie można zatem twierdzić, iż sformułowanie zawarte w ostatnim akapicie art. 28a ustawy o radiofonii i telewizji, a mianowicie „zarząd spółki zapewnia członkom rady programowe organizacyjne i finansowe warunki..." ma charakter nakazowy i bezwarunkowy.

Na koniec warto odnotować, że w niektórych przygotowywanych planach zmiany systemu mediów publicznych w Polsce, jak również konkretnych projektach nowelizacji ${ }^{26}$ zamierzano dokonać zmian w zasadach funkcjonowania rad programowych. Postulowano bowiem, aby pozostawić taki podmiot, ale umiejscowiony przy Krajowej Radzie Radiofonii i Telewizji, a nie w każdej spółce. W oparciu o dotychczasowe doświadczenia, argumentowano, iż w ten sposób rady miałyby większą efektywność pracy przy jednoczesnym obniżeniu kosztów funkcjonowania systemu mediów publicznych ${ }^{27}$.

26 Zob. np. J. Skrzypczak, Założenia przebudowy systemu publicznej radiofonii i telewizji w projekcie ustawy o zadaniach publicznych $w$ dziedzinie ustug medialnych zespolu ekspertów Ministra Kultury i Dziedzictwa Narodowego z 30 listopada 2008 r., „Środkowoeuropejskie Studia Polityczne” 2009, nr 3-4, s. 75.

27 R. Chruściak, op. cit., s. 242. 


\section{Summary}

The powers of an advisory board are laid down in the currently binding Section 3 , Art. 28a of the law. Said provision stipulates that the board passes resolutions concerning radio and television program (when gaining a majority of votes cast and the presence of at least a half of board members) and comprising the assessment of the level and quality of the running program and program schedule. This provision also stipulates that such resolutions are debated and decided by the supervisory board. It is rightfully observed in the doctrine that the advisory board is only an advising and consultative body for the corporation organs, and it only handles programming matters. The provision stipulates the principles and forms of operation of such bodies to only a limited extent. We also have to agree with the opinion that the powers of the program board are limited to program-related matters exclusively, that is to the selection of individual programs, proportions between them and general principles of radio and television operation. Thus, the board does not have a basis on which to take a stand in personnel, technical, business and legal matters, etc. 